\title{
COMPOSITION OF MEDIUM AND LARGE MAMMALS IN FOREST RESERVE IN THE CERRADO OF BRAZIL CENTRAL ${ }^{1}$
}

Rodrigo Jose Viana Leite ${ }^{2 *}$, João Lucas Franco Lemos ${ }^{2}$, Fábio William Martins da Silva ${ }^{2}$, Isis Rhaysa Castro de Alencar ${ }^{2}$, Priscila Freitas Bezerra ${ }^{2}$ and Juliano Bonfim Carregaro ${ }^{3}$

\footnotetext{
${ }^{1}$ Received on 27.02.2013 accepted for publication on 08.09.2016.

${ }^{2}$ Faculdade Anhanguera de Brasília, Graduação em Ciências Biológicas, Brasília, DF - Brasil. E-mail: <rodrigobioma@gmail.com>, <lucasjoao86@gmail.com>,<fabiowillian.mds@hotmail.com>,<isisrhaysa@hotmail.com> and < priscila.freitas23@hotmail.com>.

${ }^{3}$ Faculdade Anhanguera de Brasília, Departamento de Ciências Biológicas, Brasília, DF - Brasil. E-mail: <julianocarregaro@yahoo.com>. *Corresponding author.
}

\begin{abstract}
Knowledge about fauna location and distribution is very important for animal biology understanding. Conservation Units are relevant to biodiversity when considering factors such as hunting, agricultural expansion and forest fires. The conservation of native vegetation fragments under more suitable management plans, recovery areas and surveys are essential to the mammals preservation. This study aimed to survey the mammals of medium and large size of the Brasilia National Forest Area 1. To carry out this study it was performed weekly rounds in search for direct and indirect mammals traces existing at forest reserve. It is reported the presence of 27 species in the study area. According to the IUCN Red List, four species are vulnerable to extinction: tapir (Tapirus terrestris), giant anteater (Myrmecophaga tridactyla), giant armadillo (Priodontes maximus) and oncilla (Leopardus guttulus). Two species were recorded nearly threatened species: maned wolf(Chrysocyon brachyurus) and pampas deer (Ozotocerus bezoarticus). Also according to the same list, $48 \%(\mathrm{n}=13)$ of species are declining in population trend and $26 \%(\mathrm{n}=7)$ for this data is unknown. Differences in the area were observed, with mammal species presence associated to Cerrado vegetation types and in distribution of records over the period.
\end{abstract}

Keywords: Mammals; Traces; Cerrado.

\section{COMPOSIÇÃO DE MÉDIOS E GRANDES MAMÍFEROS EM RESERVA FLORESTAL NO CERRADO DO BRASIL CENTRAL}

\begin{abstract}
RESUMO-O conhecimento sobre a localização e a distribuição da fauna é muito importante para entendimento da biologia animal. As Unidades de Conservação (UC) são relevantes para biodiversidade quando se consideram fatores como a caça, a expansão agropecuária e os incêndios florestais. A conservação dos fragmentos de vegetação nativa com planos de manejo mais adequados, recuperação de áreas e levantamentos, são essenciais para preservação da mastofauna. O presente estudo teve por objetivo realizar o levantamento da mastofauna de médio e grande porte da Área 1 da Floresta Nacional de Brasília. Para realização do presente estudo foram realizadas rondas semanais em busca de vestígios diretos e indiretos da mastofauna existente na UC. Foi registrada a presença de 27 espécies na área estudada. De acordo com a lista vermelha da IUCN, quatro espécies estão vulneráveis à extinção: anta (Tapirus terrestris), tamanduá-bandeira (Myrmecophaga tridactyla), tatu-canastra (Priodontes maximus) e gato-do-mato-pequeno (Leopardus guttulus). Houve registro de duas espécies quase ameaçadas: lobo-guará (Chrysocyon brachyurus) e veado campeiro (Ozotocerus bezoarticus). Ainda de acordo com a mesma lista, 48\% $(n=13)$ das espécies se encontram com tendência populacional em declínio e para $26 \%(n=7)$ esse dado é desconhecido. Foram observadas diferenças no uso da área, com a presença das espécies mais associada às fitofisionomias do Cerrado, e na forma de distribuição dos registros ao longo do período.
\end{abstract}

Palavras-chave: Mastofauna; Vestígios; Cerrado. 


\section{INTRODUCTION}

Knowledge about fauna location and distribution is very important for animal biology understanding. Mammal surveys can provide information on the occurrence of the species in this group, promoting the knowledge of the composition of these animals in a given place and time (ANTUNES; ESTON, 2009; SILVA; HENRIQUES, 2009; SILVEIRA et al., 2010; CARMIGNOTTO; AIRES, 2011). From this information it can be planned strategies to plans and studies applied to mammals (ARAÚJO et al., 2008; COSTA et al., 2010).

Conservation Units has a protective role of natural resources and wildlife strengthened when human impact is a considered important factors for the various ecosystems (SALVADOR; RIBEIRO, 2011; COSTA et al., 2012a). Given the advance of human activities, many reserved areas have become refuge for several species of mammals that pass by losses and various threats (CAVALCANTE et al., 2010; CHAGAS et al., 2010).

An example of threat to mammals is the increasing of the road network and the intensification of automobile traffic in recent years, with the occurrence of road accidents of terrestrial fauna associated with the suppression of native vegetation. Thus, some mammals, especially those that are large, are or may become animals under some risk of extinction due to the recurring threat to remaining populations (CUNHA et al., 2010; CÁCERES et al., 2012).

The remnants of native vegetation, development of appropriate management plans, development of actions for the recovery of degraded areas and surveying are essential for the mammals' conservation (ANTUNES; ESTON, 2009; ROCHA; SILVA, 2009; ALVES etal., 2012). Preserved areas of native vegetation and adjacent corridors directly contribute to the maintenance of mammalian diversity, and make sustainable environment for existing populations of wild mammals in one place (SILVA; HENRIQUES, 2009; DANTAS; DONATO, 2011).

A study in 2010 in Brasilia National Forest pointed to the presence of three species of large mammals (tapir, maned wolf and giant anteater), through direct and indirect records. The forest reserve location, native vegetation, water availability and other factors, allow the existence of more species of the group there. Thus, this study aimed to carry out a survey of medium and large mammals of the Brasilia National Forest and register the use of the area by mammals.

Revista Árvore, Viçosa-MG, v.40, n.5, p.825-832, 2016

\section{MATERIALS AND METHODS}

\subsection{Study area}

The survey was conducted in Brasilia National Forest Area $1-\mathrm{BNF}-1$ ( $15^{\circ} 45^{\prime} \mathrm{S}$ and $\left.48^{\circ} 04^{\prime} \mathrm{W}\right)$ in the period from January to December 2012. This Conservation Unit has four separate areas geographically within the Brazil's Federal District, located in the Environmental Protection Area of the "Bacia do Rio Descoberto". The forest reserve area is $3353.18 \mathrm{ha}$, the largest of the four, and has several springs that make up the "Ribeirão das Pedras" and the "Córrego dos Currais". This area has some "Cerrado" biome vegetation types: Open grassland (Campo limpo), Shrubby grassland (Campo sujo), Rocky outcrop cerrado (Campo rupestre), Vereda, Typical Cerrado (Cerrado sensu strictu) and Gallery forest. There are also large areas with the presence of introduced exotic plants (eucalyptus and pine).

\subsection{Data Colection}

To carry out this study, there were 52 weekly rounds at random in search of direct traces (views and vocalizations) and indirect (tracks, faces and foraging evidence) existing mammal at forest reserve. Rounds were held in daytime and nighttime periods in existing linear transects in BNF-1 area, as well as searches in more closed vegetation areas, including gallery forests, a total of $834 \mathrm{~km}$ performed. Records obtained were cataloged using ruler or other tool to trace the size of the reference found, the date, location and observations. Recorded tracks were deleted to avoid possible repetitions. All records were compared to the standards of each species or mammalian subgroup, with the help of the specialized literature (BECKER; DALPONTE, 2013), performed for the identification and subsequent classification. To obtain accumulation species it has been used EstimateS 8.2.0 program with the Bootstrap estimator 500 and performing randomization.

\section{RESULTS}

1146 records were obtained and 27 species of medium and large wild mammals were identified in BNF-1, with representatives of 16 families, distributed in nine group orders (Table 1).

The Red List of the International Union for Conservation of Nature - IUCN (2012) and the Ministry of the Environment of Brazil - MMA (2008) provided 
information on the risk of extinction. According IUCN, population trends differ among species of this study: $7 \%(n=2)$ showed an increasing trend (black-pencilled marmoset and nine-banded armadillo), $19 \%(\mathrm{n}=5)$ are stable (crab-eating fox, white-eared opossum, spotted paca, brazilian porcupine and six-banded armadillo), 26\% $(\mathrm{n}=7)$ have unknown data (capybara, striped hog-nosed skunk, maned wolf, hoary fox, lesser anteater, southern naked-tailed armadillo and tapeti) and $48 \%(n=13)$ are in decreasing (tapir, black howler monkey, tayra, jaguarundi, ocelot, crab-eating raccoon, cougar, south american coati, giant anteater, giant armadillo, oncilla, pampas deer and brocket deer). These data reinforce the importance of carrying out fauna surveys and population studies. The species accumulation curve obtained with the estimator pointed to 30 mammals species in BNF-1, close to the 27 species observed, strengthening the evidence of labor and significant sampling effort. (Fig. 1).

Table 1 - Taxa (order, family and species), popular name and category (LC $=$ Least concern, NT $=$ Near Threatened and $\mathrm{VU}=$ Vulnerable) in National (MMA, 2008) and International (IUCN, 2012) Red List, mammals registered in 2012 in the Brasilia National Forest Area 1, DF.

Tabela 1 - Taxa (ordem, família e espécie), nome popular e categoria (MP = Menos preocupante, $Q A=$ Quase ameaçada e VU = Vulnerável) na Lista Vermelha Nacional (MMA, 2008) e Internacional (IUCN, 2012), dos mamiferos registrados em 2012 na Área 1 da Floresta Nacional de Brasília, DF.

\begin{tabular}{|c|c|c|c|}
\hline Taxa & Popular name & MMA & IUCN \\
\hline \multicolumn{4}{|l|}{ Artiodactyla } \\
\hline \multicolumn{4}{|l|}{ Cervidae } \\
\hline Mazama gouazoubira & Veado catingueiro & & MP \\
\hline Ozotoceros bezoarticus & Veado campeiro & & QA \\
\hline \multicolumn{4}{|l|}{ Carnivora } \\
\hline \multicolumn{4}{|l|}{ Canidae } \\
\hline Cerdocyon thous & Cachorro-do-mato & & MP \\
\hline Chrysocyon brachyurus & Lobo-guará & VU & QA \\
\hline Lycalopex vetulus & Raposa-do-campo & & MP \\
\hline \multicolumn{4}{|l|}{ Felidae } \\
\hline Leopardus pardalis & Jaguatirica & VU & MP \\
\hline Leopardus guttulus & Gato-do-mato-pequeno & VU & VU \\
\hline Puma concolor & Onça-parda & VU & MP \\
\hline Puma yagouaroundi & Jaguarundi & & MP \\
\hline \multicolumn{4}{|l|}{ Mephitidae } \\
\hline Conepatus semistriatus & Jaritataca & & MP \\
\hline \multicolumn{4}{|l|}{ Mustelidae } \\
\hline Eira barbara & Irara & & MP \\
\hline \multicolumn{4}{|l|}{ Procyonidae } \\
\hline Procyon cancrivorus & Mão-pelada & & MP \\
\hline Nasua nasua & Quati & & MP \\
\hline \multicolumn{4}{|l|}{ Cingulata } \\
\hline \multicolumn{4}{|l|}{ Dasypodidae } \\
\hline Cabassous unicinctus & Tatu-de-rabo-mole & & MP \\
\hline Dasypus novemcinctus & Tatu-galinha & & MP \\
\hline Euphractus sexcinctus & Tatu-peba & & MP \\
\hline Priodontes maximus & Tatu-canastra & VU & VU \\
\hline \multicolumn{4}{|l|}{ Lagomorpha } \\
\hline \multicolumn{4}{|l|}{ Leporidae } \\
\hline Sylvilagus brasiliensis & Tapiti & & MP \\
\hline \multicolumn{4}{|l|}{ Didelphimorphia } \\
\hline \multicolumn{4}{|l|}{ Didelphidae } \\
\hline Didelphis albiventris & Gambá-de-orelha-branca & & MP \\
\hline \multicolumn{4}{|l|}{ Perissodactyla } \\
\hline Tapiridae & & & \\
\hline Tapirus terrestris & Anta & & VU \\
\hline
\end{tabular}


Table 1...

Tabela 1...

\begin{tabular}{|c|c|c|c|}
\hline \multicolumn{4}{|l|}{ Pilosa } \\
\hline \multicolumn{4}{|l|}{ Myrmecophagidae } \\
\hline Myrmecophaga tridactyla & Tamanduá-bandeira & VU & $\mathrm{VU}$ \\
\hline Tamandua tetradactyla & Tamanduá-mirim & & MP \\
\hline \multicolumn{4}{|l|}{ Primates } \\
\hline \multicolumn{4}{|l|}{ Atelidae } \\
\hline Alouatta caraya & Bugio & & MP \\
\hline \multicolumn{4}{|l|}{ Callitrichidae } \\
\hline Callithrix penicillata & Sagui-de-tufos-pretos & & MP \\
\hline \multicolumn{4}{|l|}{ Rodentia } \\
\hline \multicolumn{4}{|l|}{ Caviidae } \\
\hline Hydrochoerus hydrochaeris & Capivara & & MP \\
\hline \multicolumn{4}{|l|}{ Cuniculidae } \\
\hline Cuniculus paca & Paca & & MP \\
\hline \multicolumn{4}{|l|}{ Erethizontidae } \\
\hline Coendou prehensilis & Porco-espinho & & MP \\
\hline
\end{tabular}

There were few records of vocalization and display being the main traces isolated traces or in the form of tracks, totaling $89 \%$. All types of records were collected and sorted by species. More than a half of the species $(\mathrm{n}=15)$ had low index records (Fig. 2), which can be a low population density or evidence arise from the difficulty to obtain the traces for behavioral reasons. Some species of this study were recorded in only one of the months or have been absent for some period of the year (Table 2).

\section{DISCUSSION}

This study obtained similar results to others studies conducted in "Cerrado" areas (BOCCHIGLIERI et al., 2010; LESSA et al., 2012). According to Silveira (2010), some animals may exhibit seasonal records throughout the year and specific registers in large time intervals, the duration of a year or more, which may allow short records or absence of such a study. There were differences in the number of records over the study period. This information suggests that this study occurred in a short time, some species would not be listed (Table 2).

Surveying guide and strengthen conservation actions in a given area allows a better animal survival (CHAGAS et al., 2010; TIEPOLO et al., 2010; VIDOLIN et al., 2011). Animal occurrence studies provide evidence of interest to conservation and other biological aspects. In this study, there have been many domestic dogs records (Canis familiaris) that enter mainly

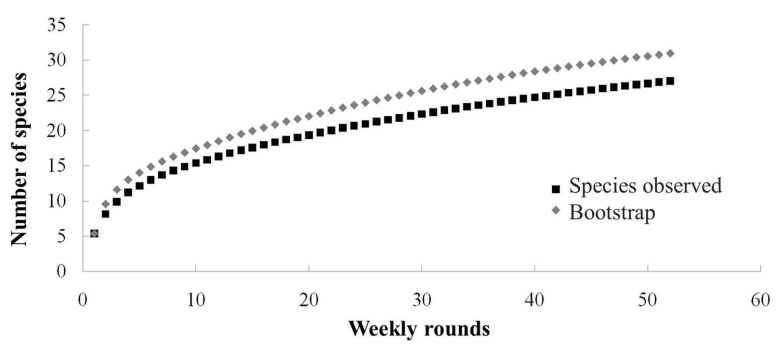

Figure 1 - Accumulation curve of species obtained with the Bootstrap estimator, through medium and large mammals records in 2012 in the Brasilia National Forest Area 1, DF.

Figura 1 - Curva de acumulação de espécies obtida com o estimador Bootstrap, através dos registros de médios e grandes mamíferos em 2012, na Área 1 da Floresta Nacional de Brasília, DF.

by southern region of the BNF-1, characterized for the proximity to residential areas. Such intrusions can promote attacks on wild animals (MENDES et al., 2005; SILVA; HENRIQUES, 2009), as was also recorded use of that region by the maned wolf, giant anteater, armadillos and crab-eating raccoon. In addition, occurrence of domestic and wild species in the same place can provide the transmission of diseases, including a potential risk for zoonosis (VARZONE et al., 2008; BRANDÃO et al., 2009; BRAGA et al., 2010). The ecological interactions possibility between wild mammals and pet signals need an action to a better local managing for biodiversity conservation (SAMPAIO; SCHMIDT, 2013) and for public health. 
On regional influences, the study area is located between full conservation areas (North), urban areas (South) and rural areas (West and East). These adjacent

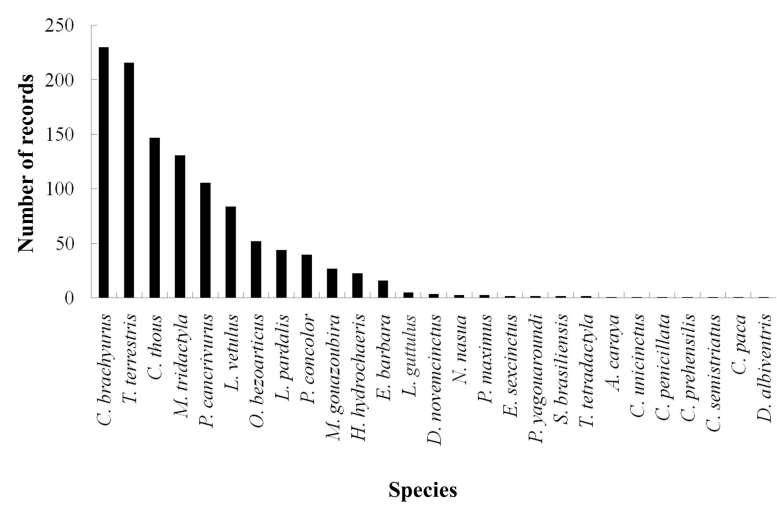

Figure 2 - Proportion of traces recorded by medium or large mammalian species in 2012 in the Brasilia National Forest Area 1, DF.

Figura 2 - Proporção de vestígios registrados em 2012, por espécie de mamífero de médio ou grande porte, na Area 1 da Floresta Nacional de Brasília, DF. regions may act in several ways on site. This may favor or not to the survival of some species recorded as many mammals cannot tolerate large changes, such as giant anteater (BRAGA, 2010) and tapir (BACHAND et al., 2009), for example. DF-001 highway establishes the main border between Brasilia National Forest and the Brasilia National Park (North), which may represent risk for wild roadkill accidents (CÁCERES et al., 2012; HEGEL et al., 2012) due to possible shifts of animals between these protected areas. The four vulnerable species of this study present case record on the edge of the area of the BNF-1 and next to that National Park. In addition to these species, there were the maned wolf, pampas deer, jaguarundi, cougars, raccoons and the hoary fox in the same place. Protected areas studies can contribute to the survival of the remaining populations of the region (COSTA et al., 2012b).

In Northern of the BNF-1 is born "Ribeirão das Pedras", characterized by the presence of gallery forest along the route and frequently visited by mammals, amounts to approximately seven kilometers protected.

Table 2 - Recorded occurrences of mammal species during the months of 2012 in the Brasilia National Forest Area 1, DF. Tabela 2 - Ocorrências registradas das espécies de mamíferos no decorrer dos meses de 2012, na Área 1 da Floresta Nacional de Brasília, $D F$.

\begin{tabular}{|c|c|c|c|c|c|c|c|c|c|c|c|c|}
\hline Species & Jan & Fev & Mar & Abr & Mai & Jun & Jul & Ago & Set & Out & Nov & Dez \\
\hline Chrysocyon brachyurus & - & - & - & - & - & - & - & - & - & - & - & - \\
\hline Tapirus terrestris & - & - & - & - & - & - & - & - & - & - & - & - \\
\hline Cerdocyon thous & - & - & - & - & - & - & - & - & - & - & - & - \\
\hline Leopardus pardalis & - & - & - & - & - & - & - & - & & & - & - \\
\hline Puma concolor & - & - & - & - & & & - & - & - & - & - & - \\
\hline Lycalopex vetulus & - & & - & - & & - & - & - & - & - & - & - \\
\hline Myrmecophaga tridactyla & - & & & - & - & - & - & - & - & - & - & - \\
\hline Ozotoceros bezoarticus & - & & & & & & - & - & - & - & - & - \\
\hline Leopardus guttulus & - & - & & & & & & & & & - & \\
\hline Procyon cancrivorus & & - & - & - & - & - & - & - & - & - & - & - \\
\hline Puma yagouaroundi & & - & - & - & & & - & - & & & & \\
\hline Tamandua tetradactyla & & - & & & & & & & & & & \\
\hline Mazama gouazoubira & & - & & & - & & & - & - & - & - & \\
\hline Didelphis albiventris & & & & - & & & & & & & & \\
\hline Conepatus semistriatus & & & & - & & & & & & & & \\
\hline Priodontes maximus & & & & - & & & - & & & & - & - \\
\hline Alouatta caraya & & & & - & & & - & & & & & \\
\hline Nasua nasua & & & & - & & & & - & & & & \\
\hline Cuniculus paca & & & & & - & & & & & & & \\
\hline Dasypus novemcinctus & & & & & - & & & & & & - & - \\
\hline Euphractus sexcinctus & & & & & - & & & & & & & \\
\hline Eira barbara & & & & & & & & - & & - & & \\
\hline Coendou prehensilis & & & & & & & & - & - & & & \\
\hline Callithrix penicillata & & & & & & & & & - & & & \\
\hline Sylvilagus brasiliensis & & & & & & & & & - & & & \\
\hline Hydrochoerus hydrochaeris & & & & & & & & & - & - & - & - \\
\hline Cabassous unicinctus & & & & & & & & & & & - & \\
\hline
\end{tabular}


This flowing stream extends to the outer limits, where there is the presence of small farms and animal husbandry. At its extreme, situated in the West of Area, there are ways that allow the wild animals passage. In rural areas are recorded attacks on farm animals or for own consumption by wild species, generating a conflict between agricultural producers and the occurrence of carnivores, mainly Canidae and Felidae. There is a bird predation record by a carnivore, a grassland area in the region. In nearby points, there are occurrence records from maned wolf, dog-eating fox, ocelots and cougars. This proximity and connectivity of the rural and nature reserve areas may favor the attack and generate such conflicts (PALMEIRA et al., 2008) as well as being another point for the transmission of diseases and entry of domestic animals. In the East there is rubbish dump and waste and, further north, the BNF-2 area, now very uncharacteristic vegetation, with allotments and strong human presence. In this region they were found few records of wild mammals, with only maned wolf traces.

The vegetation of the forest reserve are diversified, with the presence of important gallery forest extensions and are surrounded by other vegetation types of the biome, as typical Cerrado and shrubby grassland. It was these regions that showed significant number of mammalian occurrences, which reinforces the importance of native vegetation for conservation of these animals on site and associated interactions (JOHNSON et al., 1999; BIZERRIL et al., 2005; ANDREAZZI et al., 2009) and values the area of forest reserve because of ecological and landscape relations carried by mammals. The presence and possible expansion of eucalyptus and pine must have attention to better management of areas with vegetation types of the Cerrado area studied.

Forest fires are another major threat to mammals. In September 2011 there was the largest fire ever recorded to this forest reserve, with the loss of three giant anteaters and other vertebrates, and maned wolf and crab-eating fox founded with injuries. At that time, it was burned over $70 \%$ of the vegetation cover, which reduced the availability of habitat and resources. They are still little known effects of fire for wildlife (FRIZZO et al., 2011). In September 2012, there was a minor fire in a typical Cerrado area and had not been affected in last year's fire. There was no loss of records for giant anteater or other mammal.

Revista Árvore, Viçosa-MG, v.40, n.5, p.825-832, 2016

\section{CONCLUSIONS}

According to a global red list, $48 \%$ of mammal species recorded in the Brasilia National Forest - Area 1 meet population trend declining and $26 \%$, this data is considered unknown, with occurrence of vulnerable species (tapir, oncilla, giant anteater and giant armadillo) and near threatened (maned wolf and pampas deer).

Differences were observed in some species in the used area with more associated presence for Cerrado vegetation types, and in distribution records form throughout the study period. Continued studies on the occurrence of the species listed in this study are important for monitoring mammals in the area used, as well as conducting population and ecological studies.

\section{REFERENCES}

ALVES, T.R.; FONSECA, R.C.B.; ENGEL, V.L. Mamíferos de médio e grande porte e sua relação com o mosaico de habitats na cuesta de Botucatu, Estado de São Paulo, Brasil. Iheringia Série Zoologia, v.102, n.2, p.150-158, 2012.

ANDREAZZI, C.; PIRES, A.; FERNANDEZ, F. Mamíferos e palmeiras neotropicais: interações em paisagens fragmentadas. Oecologia Australis v.13, n.4, p.554-574, 2009.

ANTUNES, A.Z.; ESTON, M.R. Mamíferos (Chordata: Mammalia) florestais de médio e grande porte registrados em Barreiro Rico, Anhembi, estado de São Paulo. Revista do Instituto Florestal, v.21, n.2, p.201-215, 2009.

ARAÚJO, R.M.; SOUZA, M.B.; MIRANDA, C.R.R. Densidade e tamanho populacional de mamíferos cinegéticos em duas unidades de conservação do Estado do Rio de Janeiro, Brasil. Iheringia Série Zoologia, v.98, n.3, p.391-396, 2008.

BACHAND, M.; TRUDEL, O.C.; ANSSEAU, C.; CORTEZ, J.A. Dieta de Tapirus terrestris Linnaeus em um fragmento de Mata Atlântica do Nordeste do Brasil. Revista Brasileira de Biociências, v.7, n.2, p.188-194, 2009.

BECKER, M.; DALPONTE, J.C.. Rastros de mamíferos silvestres brasileiros: um guia de campo. $3^{\mathrm{a}}$.ed. Rio de Janeiro: Technical Books, 2013. 166p. 
BIZERRIL, M.X.A.; RODRIGUES, F.H.G.; HASS, A. Fruit consumption and seed dispersal of Dimorphandra mollis Benth. (Leguminosae) by the lowland tapir in the Cerrado of Central Brazil. Brazilian Journal of Biology, v.65, n.3, p.407-413, 2005.

BOCCHIGLIERI, A.; MENDONÇA, A.F.; HENRIQUES, R.P.B. Composição e diversidade de mamíferos de médio e grande porte no Cerrado do Brasil Central. Biota Neotropica, v.10, n.3, p.169-176, 2010.

BRAGA, F.G. Ecologia e comportamento de tamanduá-bandeira Myrmecophaga tridactyla linnaeus, 1758 no município de Jaguariaíva, Paraná. 2010. 119f. Tese (Doutorado em Engenharia Florestal) -

Universidade Federal do Paraná, Curitiba, 2010.

BRAGA, R.T.; VYNNE, C.; LOYOLA, R.D. Fauna parasitária intestinal de Chrysocyon brachyurus (lobo-guará) no Parque Nacional das Emas.

Bioikos, v.24, n.1, p.49-55, 2010.

BRANDÃO, M.L.; CHAME, M.; CORDEIRO, J.L.P.; CHAVES, S.A.M. Diversidade de helmintos intestinais em mamíferos silvestres e domésticos na Caatinga do Parque Nacional Serra da Capivara, Sudeste do Piauí, Brasil. Revista Brasileira de Parasitologia Veterinária, v. 18, n.1, p.19-28, 2009.

BRASIL. - Ministério do Meio Ambiente. Livro vermelho da fauna brasileira ameaçada de extinção. Brasília, DF: 2008. v.2. 1420p. (Biodiversidade, 19)

CÁCERES, N.C.; CASELLA, J.; SANTOS, C.G. Variação espacial e sazonal atropelamentos de mamíferos no bioma Cerrado, rodovia BR 262, Sudoeste do Brasil. Mastozoología Neotropical, v.19, n.1, p.21-33, 2012.

CARMIGNOTTO, A.P.; AIRES, C.C. Non-volant mammals (Mammalia) from Estação Ecológica Serra Geral do Tocantins. Biota Neotropica, v.11, n. 1, p.313-328, 2011.

CAVALCANTE, D.G.; PINHEIRO, E.S.; MACEDO, M.A.; MARTINOT, J.F.; NASCIMENTO, A.Z.A.; MARQUES, J.P.C. Análise da vulnerabilidade ambiental de um fragmento florestal urbano na
Amazônia: Parque Estadual Sumaúma.

Sociedade \& Natureza, v.22, n.2, p.391-403, 2010.

CHAGAS, R.R.D.; SANTOS JÚNIOR, E.M.; SOUZA-ALVES, J.P., FERRARI, S.F. Fazenda Trapsa, a refuge of mammalian diversity in Sergipe, Northeastern Brazil. Revista Nordestina de Biologia, v. 19, n.2, p.35-43, 2010.

COSTA, M.D.; FERNANDES, F.A.B.; VIANA, D.H.S. Mamíferos não-voadores no Parque Municipal de Pouso Alegre, MG. Revista Brasileira de Zoociências, v.12, n.3, p.281 290, 2010.

COSTA, A.M.B.; COSTA, A.M.B.; SILVA, V.L.; SILVA, F.M. O Parque da Cidade de Natal: atual estágio de implantação da unidade de conservação. Sociedade e Território, v.24, n. 1, p.28-44, 2012a.

COSTA, M.D.; FERNANDES, F.A.B.; HILÁRIO, R.R.; GONÇALVES, A.V., SOUZA, J.M. Densidade, tamanho populacional e conservação de primatas em fragmento de Mata Atlântica no Sul do Estado de Minas Gerais, Brasil. Iheringia Série Zoologia, v.102, n.1, p.5-10, 2012b.

CUNHA, H.F.; MOREIRA, F.G.A.; SILVA, S.S. Roadkill of wild vertebrates along the GO-060 road between Goiânia and Iporá, Goiás State, Brazil. Acta Scientiarum Biological Sciences, v.32, n.3, p.257-263, 2010.

DANTAS, M.A.T.; DONATO, C.R. Registro de Lontra longicaudis (Olfers, 1818) na caverna da Pedra Branca, Maruim, Sergipe, Brasil. Scientia Plena, v. 7, n.8, p. 1-4, 2011.

FRIZZO, T.L.M.; BONIZÁRIO, C.; BORGES, M.P.; VASCONCELOS, H.L. Revisão dos efeitos do fogo sobre a fauna de formações savânicas do Brasil. Oecologia Australis, v. 15, n.2, p.365-379, 2011.

HEGEL, C.G.Z.; CONSALTER, G.C.; ZANELLA, N. Mamíferos silvestres atropelados na rodovia RS135, norte do estado do Rio Grande do Sul. Biotemas, v.25, n.2, p.165-170, 2012.

IUCN. IUCN Red List of Threatened Species. Version 2012.2. [accessed on: Nov. 2012]. Available at: www.iucnredlist.org.

Revista Árvore, Viçosa-MG, v.40, n.5, p.825-832, 2016 
JOHNSON, M.A.; SARAIVA, P.M.; COELHO, D. The role of gallery forests in the distribution of Cerrado mammals. Revista Brasileira de Biologia, v.59, n.3, p.421-427, 1999.

LESSA, L.G.; ALVES, H.; GEISE, L.; BARRETO, R.M.F. Mammals of medium and large size in a fragmented cerrado landscape in northeastern Minas Gerais State, Brazil. Check List, v.8, n.2, p.192-196, 2012.

MENDES, F.R.; MIKICH, S.B.; BIANCONI, G.V., PEDRO, W.A. Mamíferos do município de Fênix, Paraná, Brasil: etnozoologia e conservação.

Revista Brasileira de Zoologia, v.22, n.4, p.991-1002, 2005.

PALMEIRA, F.B.L.; CRAWSHAW JR, P.G.; HADDADC, C.M.; FERRAZ, K.M.P.M.B.; VERDADE, L.M. Cattle depredation by puma (Puma concolor) and jaguar (Panthera onca) in Central-western Brazil. Biological

Conservation, v.141, p.118-125, 2008.

ROCHA, E.C.; SILVA, E. Composição da mastofauna de médio e grande porte na Reserva Indígena "Parabubure", Mato Grosso, Brasil. Revista Árvore, v.33, n.3, p.451-459, 2009.

SALVADOR, D.; RIBEIRO, J. Reserva Ecológica da Sapiranga em Fortaleza/CE, as realidades de uma unidade de conservação em meio urbano.

Revista de Geografia, v.27, n.3, p.303-314, 2011.
SAMPAIO, A.B.; SCHMIDT, I.B. Espécies exóticas Invasoras em Unidades de Conservação Federais do Brasil. Biodiversidade Brasileira, v.3, n.2, p.32-49, 2013.

SILVA, K.F.M.; HENRIQUES, R.P.B. Ecologia de população e área de vida do tatu-mirim (Dasypus septemcinctus) em um Cerrado no Brasil Central. Edentata, v.8-10, p.48-53, 2009.

SILVEIRA, L.F.; BEISIEGEL, B.M.; CURCIO, F.F.; VALDUJO, P.H.; DIXO, M.; VERDADE, V.K.; MATTOX, G.M.T.; CUNNINGHAM, P.T.M. Para que servem os inventários de fauna?. Estudos Avançados, v.24, n.68, p.173-207, 2010.

TIEPOLO, L.M.; TOMAS, W.M.; BORGES, P.A.L. Levantamento populacional do cervo-do-pantanal Blastocerus dichotomus (Mammalia, Cervidae) no Parque Nacional de Ilha Grande e entorno: implicações para a conservação. Iheringia Série Zoologia, v.100, n.2, p.111-115, 2010.

VARZONE, J.R.M.; AQUINO, L.P.C.T., RODOVALHO, M.V.T. Achados macroscópicos de lesões resultantes do parasitismo por Dioctophyma renale em lobo-guará (Chrysocyon brachyurus) - relato de caso. Ensaios e Ciência, v.7, n.2, p.171-178, 2008.

VIDOLIN, G.; BIONDI, D.; WANDEMBRUCK, A. A anta (Tapirus terrestris) em fragmentos de floresta com araucária, Paraná, Brasil. Floresta, v.41, n.4, p.685-694, 2011. 